\title{
Effect of Different Types of Mulching Materials on Growth and Yield of Chilli (Capsicum annum L. Cv. Arka Harita)
}

\author{
Kumari Vibha Rani $^{1^{*}}$, U. N. Umesh ${ }^{1}$, Anil Kumar ${ }^{2}$, Suraj Prakash ${ }^{3}$ and B. K. Mandal ${ }^{4}$ \\ ${ }^{1}$ Krishi Vigyan Kendra, Nalanda, India \\ ${ }^{2}$ I. R. S. Araria, India \\ ${ }^{3}$ B. P. S. A. C. Purnea, India \\ ${ }^{4}$ Krishi Vigyan Kendra. Sekhpura, India \\ *Corresponding author
}

\section{A B S T R A C T}

\section{Keywords}

Chilli, Paddy straw mulching, Bicolour plastic (black/silver) mulching, Number of fruits, Yield, quality

\section{Article Info}

Accepted: 15 October 2020 Available Online: 10 November 2020
An on -farm trial was conducted on various farmers field in different villages of Araria district during financial year 2016-17. This trail was conducted to overcome weed infestation during cultivation of chilli in farmers field. It leads to reduction in yield; quality of produce is inferior as compared to better quality produce, increased the cost of cultivation due to manual hand weeding by laborers and reduced the benefit cost ratio. The trial was conducted in randomized block design with three treatments and ten replications. The different treatments are Technology option -1 is farmers practice, Technology option2 is use of paddy straw as mulch and Technology option-3 is use of bicolor silver/black plastic 25 micron thickness as mulch material. We got the following results as maximum plant height recorded was $78.10 \mathrm{~cm}$ in case of use of bicolor plastic mulch as compared to $72.90 \mathrm{~cm}$ in case of paddy straw as mulch material and $66.10 \mathrm{~cm}$ in case of control. The Highest average number of fruits per plant was 175.40 in case of bicolor plastic mulch as compared to 163 fruits per plant in case of paddy straw mulch and 150.40 in case of control. The maximum average weight of fruit was $4.53 \mathrm{gm}$, fruit yield per plant was $743.84 \mathrm{gm}$ and yield 89.66 quintal per hectare is recorded in case of bicolor plastic mulch as compared to $4.42 \mathrm{gm}$ per fruit, $662.57 \mathrm{gm} /$ plant and 84.24 quintal per hectare was found in case of paddy straw mulch and 3.61 gm per fruit, 579.14 gm per plant and 75.18 quintal per hectare was recorded in case of control.

\section{Introduction}

Chilli (Capsicum Annum L.) is important spice crop grown in all the tropical and subtropical regions of the world. It belongs to family Solanaceae. It is part of human diet since about $7500 \mathrm{BC}$. It is one of the oldest cultivated crops in the Americas. The origins of cultivating chilli peppers are noticed to north eastern Mexico some 6000 years ago.
It has good nutritional value. Red chilli have rich amount of vitamin $\mathrm{C}$ and pro vitamin $\mathrm{A}$. But yellow and green chilies have lesser amount of these substances as compared to matured red chilies. It also have different types of vitamin B especially vitamin B6. They are good supplement of magnesium, iron and potassium also. The dehydrated green chilies are rich source of vitamin $\mathrm{C}$. 
It has medicinal value also. It is used as a tonic and a carminative action. The oleoresin in capsicum is used in pain relief balms and vapo rubs. It is effective in treatment for sensory nerve fiber disorders, including pain associated with arthritis, psoriasis and diabetic neuropathy. The pungency in chilli is due to alkaloid present in pericarp and placenta of fruits is capsaicin.

Chilli is cultivating in an area of 1832 thousand hectares in the world with production of 2959 thousand tons. The leading growing countries are India, China, Indonesia, Korea, Pakistan, Turkey and Sri Lanka in Asia. Nigeria, Ghana, Tunisia and Egypt in Africa. Maxico, United states of America in North central America. Yugoslavia, Spain, Romania, Bulgeria, Italy and Hungary in Europe and Argentina and Peru in South America. India is leading producer of chilli in Asia followed by China and Pakistan (Source: FAO).

The leading chilli growing states of India are Andhra Pradesh (26\%), Maharashtra (15\%), Karnataka (11\%), Orissa (11\%), Madhya Pradesh (7\%) and 22\% in other states. Andhra Pradesh tops among list of dry chilli production followed by Tamilnadu, Maharashtra, Orissa and Karnataka. In India production is dominated by Andhra Pradesh (57\%), Karnataka (12\%), Orissa (5\%), West Bengal (5\%), Maharashtra (4\%), Madhya Pradesh (3\%) and other states about $14 \%$ during 2006-07 (Source, Spice board, India).

Chilli is heavy feeder of manure and long duration crop. It requires balanced dose of fertilizer along with proper intercultural operations, moisture level for better yield and quality of produce (Prasad et al., 2009). The crop of chilli is indeterminate in nature. The vegetative and reproductive phases of crop overlap to each other and require nutrition and irrigation up to fruit ripening and maturity.
The reason for water stress is difficult to explain (Begg and Turner, 1976). At the time of flower initiation, during flowering period and up to some extent during fruit development most of the determinate crops are highly sensitive to water stress (Hegde, 1989). The chilli seedlings are sensitive to excess and deficit water but younger is more sensitive as compared to older one (Ayoub, 1986).

Mulch is a material that spread on the surface of soil for conserving moisture, reducing weed infestation on the surface of soil and near vegetation. It also reduces pest and disease incidence in crops. There are two types of mulch materials that are used (a) organic mulch (b) inorganic mulch. In case of organic mulch we are using straw of different crops, dry leaves, grass clipping etc as mulch material. In case of inorganic mulch we are using different types of poly ethylene film as mulch material. In perennial crops generally mulches like polyethylene film, plastic mulch, synthetic mulch etc is used (Memon et al., 2017).

The increase in yield of brinjal with the use of transparent foil, poly ethylene film and poly propylene by $28.3 \%, 15.9 \%$ and $11.6 \%$ respectively as compared to conventional method of cultivation (Sowinska et al., 2016). The mulching showed better result on crop growth, yield and different cropping species (Ashworth and Harrison, 1983). The quality and yield attributes of different vegetable crop can be improved by application of plastic mulch (Raina et al., 1999; Bharadwaj, 2013).

\section{Soil properties of the Araria district}

There are two broad soil groups are available in the district. Alluvium non-calcareous nonsaline groups of soil found in most part of the district. The texture of the soil is light to medium and nature is slightly acidic to 
neutral. Trai soils found in north east part of the district. Its texture is light to heavy and poorly drained soil.

The soil of entire Araria district is suitable for all agricultural activities. The major crops grown in the district is paddy, maize, pulses and different types of vegetables. Some local fruits also grown in the district due to its suitability to soil and agro climatic conditions.

There is no horizontal differentiation found in the layered sediments. In north east corner of the district tarai soils are found in small patch. Its composition is highly disturbed recent alluvium. It is ill drained and light to heavy in texture.

The soil properties of Araria district varies in following range as $\mathrm{pH}$ from 5.8 to 7.4 , EC from 0.2 to $1.35 \mathrm{dS} / \mathrm{m}$, organic carbon from 0.2 to $0.86 \%$, available nitrogen from $110-550$ $\mathrm{kg} / \mathrm{ha}$, available $\mathrm{P}_{2} \mathrm{O}_{5}$ from $20-55 \mathrm{~kg} / \mathrm{ha}$ and available $\mathrm{K}_{2} \mathrm{O} 78-350 \mathrm{~kg} / \mathrm{ha}$.

The initial soil properties of farmers plots was found as average $\mathrm{pH}$ value of soil is 6.8, average electrical conductivity of soil is 0.75 $\mathrm{dS} / \mathrm{m}$, organic carbon is $0.65 \%$, available nitrogen was $375 \mathrm{~kg}$ per hectare, available $\mathrm{P}_{2} \mathrm{O}_{5}$ was $35 \mathrm{~kg}$ per hectare and available $\mathrm{K}_{2} \mathrm{O}$ was $180 \mathrm{~kg}$ per hectare.

The post harvest soil properties of farmers' plots are varies according to different treatments. The nutrient status of soil in case of paddy mulch application is improved as compared to other treatment details as mentioned in table no-1.

The table no- 1 shows that effect of mulching increases organic carbon, available nitrogen and available potash significantly as compared to farmers practice and other soil parameters are at par.

\section{Materials and Methods}

The location of Araria district is in north eastern corner of Bihar state with its international boundary in the nirth is Nepal. Adjoining districts are Supaul in the west, Purnea in the south, Madhepura in the southwest and Kisanganj in the east. The district is situated at latitudes $25^{\circ} 56^{\prime} 30^{\prime \prime}$ ' to $26^{\circ} 35^{\prime} 15^{\prime \prime}$ north and longitude 87002 ' 30"' to 870 42' 45 ' east. The district has a geographical area of 2830 square meter.

An on farm trial was conducted on different farmers' field of various villages of the district in Randomized block design. The experiments was conducted during financial year 2016-17 with the chilli variety Arka Hrita. The trial was conducted on ten farmers' field with three replication.

Technology option -1 is farmers practice (Manual hand weeding)

Technology option -2 is mulching with paddy straw (6cm thickness)

Technology option -3 is Bicolour (Silver/ Black) plastic mulch with 25 micron thickness

The paddy straw mulch spread on raised bed after transplanting of seedling at a distance of $50 * 50 \mathrm{~cm}$. The black plastic mulch was fixed tightly on the raised bed with both ends and sides are buried properly in the soil. After that holes are made at $50 * 55 \mathrm{~cm}$ and then transplanting of seedlings was done.

In case of control after transplanting of seedlings hand weeding by labourers to control weed infestation. Observation of different parameters like average number of fruits per plant, yield quintal per hectare and economic components was studied. 


\section{Results and Discussion}

\section{Effect of mulch material on plant growth}

As per trial findings maximum height of the plant is $78.10 \mathrm{~cm}$ in case of bicolour (black/silver) plastic mulch as compared to paddy straw mulch and control as per table no 2.

Similar result was found in case of Maida et al., (2019) the maximum height was reported in case of silver plastic mulch. The higher growth of plant is due to enhanced soil temperature, reflected sunlight, lesser evapo transpiration and maintained soil moisture due to use of plastic mulch. The improvement in microclimatic condition due to use of mulch leads to higher plant height and higher number of primary and secondary branches. Same results was recorded in chilli by Ashrafuzzaman et al., (2011), in okra by Gordon et al., (2010) and in tomato by Christopher et al., (1996). As per findings of Shinde et al., (1999) the maximum plant height was recorded in case of use of plastic mulch as compared to other mulch material.

The use of plastic mulch leads to increased moisture retention capacity of soil due to lesser evaporation. As per findings of Wang et al., (1998) the soil moisture content in chilli plot is more as compared to control in use of plastic mulch. As per findings of Prajapati et al., (2017) the plant height of chilli plants are increased due to optimum availability of soil moisture and regulated optimum soil temperature.

Similar findings were recorded by Ashrafuzzaman et al., (2011) and Lourduraj et al., (1996) in case of chilli plant. Due to favorable weather condition provided by use of mulch material leads to increased number of branches per plant as per findings of Shrivastava et al., (1994) in tomato plant.
Various factors like moisture conservation, maintainace of soil temperature are influenced by use of mulch material through suppressing growth of weeds. Similar results was found in dry chilli by Ramakrishna (2002), in green chilli by Ayodele et al., (2015), Tumbare and Nikam (2004), Gulshan et al., (2007), Prabhakar et al., (2010) and Pandey et al., (2013) and in case of tomato by Ranjan et al., (2014).

\section{Number of fruits per plant}

The maximum average number of fruit per plant was recorded in case of plastic mulch is 175.40 as compared to paddy straw mulch (163.00) and 150.40 in case of farmers practice (control).

Similar findings were recorded in chilli as per Prajapati et al., (2017) and Singh et al., (2002) in tomato. The increase in number of fruit per plant was associated with improved microclimate above and below the soil surface as well as improved moisture conservation as compared to farmers' practices (control). The maximum number of fruit per plant was also reported by Singh $e t$ al., (2017) in case of use of plastic mulch as compared to control in tomato. The similar findings were recorded by Hedau N., (1998) and Rahman et al., (2016) in tomato in case of use of plastic mulch as compared to control. As per findings of Kumar et al (2019) the maximum average number of fruits per plant was recorded as compared to control in brinjal.

The maximum number of fruits per plant was recorded in black plastic mulch (472 per plant) as compared to control (335 per plant) as per Ashrafuzzaman et al., (2011). As per findings of Ravinder et al., (1997) the number of fruits per plant increased and decreased the fruit abortion percentage as compared to control in chilli plot. 
Table.1 Effect of mulching on post harvest soil properties of experimental plots

\begin{tabular}{|c|c|c|c|c|c|c|}
\hline \multirow[t]{2}{*}{ Treatments } & \multirow[t]{2}{*}{ pH } & \multirow[t]{2}{*}{$\mathrm{EC}(\mathrm{dS} / \mathrm{m})$} & \multirow{2}{*}{$\begin{array}{l}\text { Orgenic } \\
\text { carbon }(\%)\end{array}$} & \multicolumn{3}{|c|}{ Available nutrients (kg/ha) } \\
\hline & & & & $\mathrm{N}$ & $\mathrm{P} 2 \mathrm{O} 5$ & $\mathrm{~K} 2 \mathrm{O}$ \\
\hline Farmers practice & 6.80 & 0.748 & 0.647 & 372 & 36 & 182 \\
\hline $\begin{array}{l}\text { Use of paddy straw as } \\
\text { mulch material }(6 \mathrm{~cm} \\
\text { thickness) }\end{array}$ & 6.78 & 0.742 & 0.654 & 380 & 33.8 & 186 \\
\hline $\begin{array}{l}\text { Use of bicolour } \\
\text { (Silver/black) plastic as } \\
\text { mulch ( } 25 \text { micron thickness) }\end{array}$ & 6.81 & 0.745 & 0.649 & 376 & 35 & 181 \\
\hline $\begin{array}{l}\text { S.Em.+ } \\
\text { C.D.@5\% }\end{array}$ & $\begin{array}{l}.02 \\
\text { NS }\end{array}$ & $\begin{array}{l}0.002 \\
\text { NS }\end{array}$ & $\begin{array}{l}0.002 \\
0.006\end{array}$ & $\begin{array}{l}2.21 \\
6.62\end{array}$ & $\begin{array}{l}0.76 \\
\text { NS }\end{array}$ & $\begin{array}{l}2.32 \\
6.95\end{array}$ \\
\hline
\end{tabular}

Table.2 Effect of mulching on different quantitative and qualitative parameters in chilli Cv. Arka Harita

\begin{tabular}{|l|c|c|c|c|c|}
\hline Treatments & $\begin{array}{c}\text { Plant height } \\
\text { cm }\end{array}$ & $\begin{array}{c}\text { Number of } \\
\text { fruits per } \\
\text { plant }\end{array}$ & $\begin{array}{c}\text { Average } \\
\text { weight of fruit } \\
\text { in gram }\end{array}$ & $\begin{array}{c}\text { Yield per } \\
\text { plant in } \\
\text { gram }\end{array}$ & $\begin{array}{c}\text { Yield quintal } \\
\text { per hectare }\end{array}$ \\
\hline Farmers practice & 66.10 & 150.40 & 3.61 & 579.14 & 75.18 \\
\hline $\begin{array}{l}\text { Use of paddy straw as mulch } \\
\text { material (6cm thickness) }\end{array}$ & 72.90 & 163.00 & 4.42 & 662.57 & 84.24 \\
\hline $\begin{array}{l}\text { Use of bicolour } \\
\text { (Silver/black) plastic as }\end{array}$ & 78.10 & 175.40 & 4.53 & 743.84 & 89.66 \\
\hline mulch (25 micron thickness) & & & & & \\
\hline $\begin{array}{l}\text { S.Em.+ } \\
\text { C.D.@5\% }\end{array}$ & 0.428 & 0.627 & 0.007 & 0.767 & 0.41 \\
\hline
\end{tabular}

Yield parameters

\section{Average weight of fruit}

The highest fruit weight is $4.53 \mathrm{gm}$ is recorded in bicolor plastic mulch as compared to farmers practice (control) is $3.61 \mathrm{gm}$. The similar result was also recorded in findings of Maida et al., 2019.

\section{Fruit yield per plant}

The maximum average fruit yield per plant is recorded in bicolour plastic mulch is 743.84 gm per plant as compared to $662.57 \mathrm{gm}$ per plant in case of paddy straw mulch and $579.14 \mathrm{gm}$ per plant in case of farmers practice (control). The average yield of plot is 89.66 quintal per hectare in case of bicolour plastic mulch as compared to 84.24 quintal per hectare in case of paddy straw mulch and 75.18 quintal per hectare in case of farmers practice (control).

The similar findings were also recorded by Maida et al., (2019) and Ashrafuzzaman et al., (2011) in case of chilli cultivation. The highest fruit yield of mulched plot was associated with weed control. Conservation of moisture above and beneath the soil surface, decrease in pest and disease incidence improved the plant growth and yield as compared to unmulched plot. As per findings of Kumar et al., (2016) the highest yield of 
green chilli was 20.20 tones per hectare with $38 \%$ increase in yield as compared to unmulched treatment. Similar findings was also observed by Singh R., (2005), Mukherjee et al., (2010), Singh and Kamal (2012), Ogundare et al., (2015) and Hedau N., (1998) in case of fruit yield in black and double shaded mulch.

As per findings of Ashrafuzzaman. M. et al., fruit yield of chili per plant and per hectare yield is increased due to effect of different plastic mulch as compared to control. The increase in yield in mulched plot due to increase in number of fruit per plant. The similar findings were recorded by Siborlabane (2000) in case of tomato cultivation.

In conclusion as per findings of on-farm trial conducted that bicolour plastic mulch gives best result in case of number of fruits per plant, weight of fruit per plant, yield, reduction in weed infestation etc. as compared to other treatments. Although soil fertility status improved in application of paddy straw as mulch. The organic carbon percentage, available nitrogen, available $\mathrm{P} 2 \mathrm{O} 5$ and available $\mathrm{K} 2 \mathrm{O}$ increased in soil as compared to other treatments.

\section{References}

Ahmed MSM, Manal MH, Moula GE, Farag AA, Aly AMM (2016). Response of egg plant (Solanum melongena L.) to application of some organic fertilizers under different colours of plastic mulch, Middle East Journal of Agriculture Research.: 5(4):636-646.

Arin L, Sozer A (2001). Effect of low-tunnel, mulch and pruning on the yield and earliness of tomato in unheated glasshouse. J. Appl. Hortic. 3(1): 23-27.

Ashrafuzzaman M., Halim M.A., Ismail M.R., Shahidullah S.M., and Hossain M.A. (2011). Effect of plastic mulch on growth and yield of chilli (Capsicum annuum L.). Brazilian Archives of Bio. And Tech. 54(2), 321-330.

Ayodele, O.J., E.O. Alabi and M. Aluko (2015). Nitrogen fertilizer effects on growth, yield and chemical composition of hot pepper (Rodo). Int J. Agric. Crop Sci., 8(5):666-673.

Ayoub K (1986). Effect of available soil moisture on the yield of chilli (Capsicum annum). Technology Sayur Sayuran, 2, 57-59.

Begg J.E. and Turner, T.C. (1976). Crop water deficits. Adv.Agron., 28,161-217.

Choudhary, V.K. and Bhambri, M.C.2012. Agro-economic potential of capsicum with drip irrigation and mulching. SAARC J Agri., 10(2):51-60.

Christopher L.A, Sreenarayanan VV, Rajendran R.R.V, Padmini $\mathrm{K}$ and Pandiarajan T.(1996). Effect of plastic mulching on tomato yield and economics. South Indian Horticulture,44(5\&6)139-142.

Farias Larios J, Orozco Santos M(1997). Effect of polyethylene mulch colour on aphid populations, soil temperature, fruit quality and yield of watermelon under tropical conditions, New Zealand J. Crop and Horti. Sci.25(4):369-374.

Gordon GG,Foshee GW, Reed ST, Brown JE and Vinson EL. (2010). The effects of colored plastic mulches and row covers on the growth and yield of okra. Hort. Technology. 20(1): 224-233.

Gulshan M., K.G. Singh, S. Rakesh and Mukesh siag (2007). Response to red hot pepper (Capsicum annuum L.) to water and nitrogen under drip and check basin method irrigation. Asian J.Plant Sci., 6(5):815-820.

Ham JM, Kluitenberg GJ, Lamont WJ (1991). Potential impact of plastic mulches on the aboveground plant environment. Proc. Natl. Agric. Plastics Congr.23: 63-69.

Hedau N (1998). Effect of nitrogen level and mulch material on yield and quality characters of tomato. M.Sc Thesis. Department of vegetable science, Dr. Y.S. Parmar university of horticulture 
and forestry.Nauni.India:24.

Hedge, D.M. (1989), Effect of soil moisture and nitrogen on plant water relations, mineral composition and productivity of bell pepper (Capsicum annum L.). Indian J. Agron., 34, 30-34.

Incalcaterra G, Iapichino G, Vetrano F (2004). Effects of transparent polythene mulching and different planting densities on tomato grown foe processing in Sicily. Dipartimento ACEP, Sezione di orticoltura e floricoltura, Universita di Palermo, Viale delle Scienze, Palermo, Italy.

Kumara N., Loganandhan N., Somashekhar and Gowda H.B. (2016). Effect of black polythene mulches on growth and yield of green chilli (Capsicum annuum) in Tumkur district, Karnataka.15, pp.201204.

Kumar P, Kumar S, Kumari M and Kumar V. (2019). Effect of mulching on brinjal cultivation. 8(3): 624-629.

Lamont WJ (1999). The use of different coloured mulches for yield and earliness. Proceedings of the New England vegetable and berry growers conference and trade show, Sturbridge, Mass. pp. 299-302.

Lourduraj A.C., Sreenarayanan V.V., Rajendran R., Ravi V., Padmini K. and Pandiarajan T. (1996) South Indian horticulture, 44: 139-142.

Maida P, Bisen B.P. and Diwan G.(2019). Effect of plastic mulch on growth and yield of chilli (Capsicum annuum L.). 8(12): 2056-2062.

Melek E, Atilla D (2009). Effect of different mulch materials on the plant growth, some quality parameters and yield of melon (Cucumis melo L) cultivars in high altitude environmental condition. J.Pak.Bot. 41(4): 1891-1901.

Mukherjee A, Kundu M and Sarkar S(2010). Role of irrigation and mulch on yield, evapotranspiration rate and water use pattern of tomato (Lycopersicon esculentum L.). Agricultural water management. 98: 182-189.
Ogundare S.K, Babatunde I.J and Etukudo OO (2015). Response of tomato variety (Roma) yield to different mulch materials and staking in Kabba, Kogi state, Nigeria. J. Agril Studies.3:61-70.

Pandey, A.K., A.K. Singh, A. Kumar and S.K. Singh (2013). Effect of drip irrigation, spacing and nitrogen fertigation on productivity of chilli (Capsicum annuum L.) Environ Ecol., 31(1):139142.

Prabhakar, B.N., B.K. Ramachandrappa, H.V.S Nanjappa and T M. Soumya (2010). Effect of frequency and methods of fertigation on growth, yield, quality and economics of green chilli (Capsicum annuum L.). Mysore J.Agric. Sci., 44(3): 523-528.

Prajapati O.P., Gupta P.K., Lekhi R., Patidar J. and Jatav R.,(2017). Effect of different mulches on growth, yield and its attributing characters of chilli (Capsicum annuum L.) Cv. Kalipeeth.64(8):3599-3602.

Quadir MA. (1992). Mulching effects on fruit yield of watermelon, Agril. Sci. Digest. 12(1):1-3.

Rajan, K., A. Abdul Haris, I.K. Prasad and Shivan (2014). Efficacy of conventional, solid soluble and liquid fertilizers applied through dripfertigation on tomato. Indian J. Hort., 71(2): 217-221.

Rahman M.J, Quamruzzaman M, Samsuddin M (2016). Effect of different mulch materials on growth and yield of tomato. Bangladesh Horticulture. 2: 2937.

Ramakrishana, T. (2002). Effect of plant geometry and fertilizer levels on growth, yield and quality of chilli (Cv.Vietnam-2). M.Sc (Agri). Thesis university of Agril. Sci. Dharwad.

Ravinder, K., Srivastava, B.K. and Kumar, R. (1997). Effect of different mulch materials on the soil temperature and moisture in winter tomato. Crop Res., 14,137-141.

Romic D, Borosic J, Poljak M, Romic M(2003). 
Polyethylene mulches and drip irrigation increase growth and yield in watermelon (Citrullus lanatus L.), European J. Horti. Sci. 68(4):192-198.

Rudich J, Elassar G, Shefi Y. (1978). Optimal growth stages for the application of drip irrigation to muskmelon and watermelon. J. Horti. Sci; 53(1):11-15.

Schonbeck, M.W. (1998). Weed suppression and labour costs associated with organic, plastic, and paper mulches in small scale vegetable production. J. Sustain. Agric. 13, 13-33.

Shind, U.R., Firake, N.N., Dhotery, R.S. and Banker, M.C. (1999). Effect of micro irrigation systems and mulches on microclimate factors and development of crop coefficient models for summer chilli. Maharastra Agril. Univ. J., 24, 72-75.

Shrivastava P.K., Parikh M.M., Sawani N.G. and Raman S. (1994). Effect of agricultural water management. 2525(2): 179-184.

Singh AK and Kamal S. (2012). Effect of black plastic mulch on soil temperature and tomato yield in mid hills of Garhwal Himalayas. J. Horti Forestry.4:78-80.

Singh, B., Kumar M. and Singh G.C. (2005) Indian J. of Hort., 62(2): 200-202.
Singh H, Sharma P, Kumar P, Dhillon S. N. and Sekhon S.B.(2017). Influence of mulching on growth and yield of tomato (Solanum lycopersicum L.) under protected environment. Biotech. J. Inter., 19(2):1-6.

Singh, R (2005). Influence of mulching on growth and yield of tomato (Solanum lycopersicum L.) in north Indian plains. J. Veget Sci. 32:55-58.

Tumbare, A.D. and D.R. Nikam (2004). Effect of planting and fertigation on growth and yield of green chilli (Capsicum annuum L.). Indian J. Agri. Sci., 72(2): 95-102.

Wang, X.Q., Li, S.X. and Gao, Y.J. (1998). Effect of plastic film mulching on ecophysiology and yield of spring maize on arid lands. Acta Aggronomica Sinica. 24, 348-353.

Wolsk Gajc (2004). Effect of black mulch on quality of watermelon cultivars, Food Nutr. Sci. 57(3):147-149.

Zhang, B.Y., Chen, H.G. and Zhou, T.W. (1992). Exploration on coloured plastic film mulch for controlled weeds in tomato and maize fields. Plant protection, 6, 40-41.

\section{How to cite this article:}

Kumari Vibha Rani, U. N. Umesh, Anil Kumar, Suraj Prakash, and B. K. Mandal Krishi Vigyan Kendra, Nalanda, I. R. S. Araria, B. P. S. A. C. Purnea and Sekhpura, K. V. K. 2020. Effect of Different Types of Mulching Materials on Growth and Yield of Chilli (Capsicum annum L. Cv. Arka Harita). Int.J.Curr.Microbiol.App.Sci. 9(11): 2005-2012. doi: https://doi.org/10.20546/ijcmas.2020.911.238 